economic crops and products in the denuded areas which will provide an alternative to this high percentage of absentees from home, but hitherto without success. Pending the expert investigation of the Institute, any suggestion as to a possible solution may seem premature; but it is evident that the situation is one of urgency.

\section{Metallurgy and Prehistory}

ONE of the more useful, if less obtrusive, functions of the British Association has been the assistance given by modest subsidies in initiating lines of research, which could offer little to attract support from the sources commonly available. Not infrequently the result has been out of proportion to this modest beginning. What would appear likely to become an instance in point is the research committee on Sumerian copper, from which a report was presented at the Cambridge meeting. This committee was first appointed some years ago for the purpose of investigating by comparative analysis the provenance of the copper in objects found by archæological excavation on Sumerian sites-a question of no little moment in determining the cultural contacts of the early peoples of Mesopotamia. Since then samples of early copper and bronze from a large number of sites have been examined, and a quantity of valuable data has been collected in the investigations which have been carried out under the direction of Dr. C. H. Desch, who has acted as secretary of the committee since its inception. Archæologists now recognize the advantage of the facilities for such an examination of their material by a committee which has at its disposal a technique developed by experience and a staff now familiar with the analysis of such metals and with the characteristics of ores from various regions mined in antiquity. In the period under review in the current report, for example, it is stated that analyses were made of prehistoric copper from Anatolia and India, of slags from Persia, of bronzes from central Asia and Brittany, of bronze and copper objects from Troy ix, and of electrum from Tell Ajjul in Palestine, while Sir Robert Mond's excavations in Guernsey have led to the microscopic investigation of early iron, and much information has, in consequence, been collected about the structure of bloomery iron. This work has been carried out at the National Physical Laboratory; but the readiness of archæologists to seek the assistance of the committee has led to the suggestion that it should be placed upon a more permanent basis and given a more general title.

\section{Meare Lake Village, Somerset}

Work has been resumed at the Meare Lake Village, Somerset, for the season of 1938 under the direction of Dr. Arthur Bulleid and Mr. H. St. George Gray, and will continue until September 17. Operations this year are being concentrated on the middle area of the eastern half of the village, and at the moment, it is reported in The Times of September 2, the dwelling known as No. xxiv is under examination. In the southern section of this dwelling three floors can be seen. Two hearths have been uncovered, while near by there is a third, which belongs to the lowest floor. A number of lias stones have been found lying about this hearth. One of these is in an upright position. It is conjectured that it may have been the back of a seat set around the fire. On the east side of this hearth parallel timbers of oak lie on the surface of the peat. The small finds indicate that the inhabitants of the dwelling followed the occupation of weavers. Sawn and cut lengths of red deer antler and several pieces of iron are included among the finds, as well as the rim of a bowl in bronze. Personal ornaments are represented by a spiral finger ring of bronze, and an amber bead inlaid with a spiral ornament in fused white material. Funds for the continuation of the excavations are urgently needed. It is much to be desired that the investigation of this important Iron Age site should be in no way hampered or delayed by lack of funds, for the results of investigations of the western half of the village have been prepared for publication and will be issued shortly. Their value will be impaired if investigation of the village as a whole falls short of completeness. Subscriptions may be sent to Mr. H. St. George Gray, The Castle Taunton.

\section{Hittites in Syria}

SIR LeONard Woolley's investigations at Atchana in the Amk Plain of Syria near Antioch have continued to extend the evidence of Hittite occupation. There is now a strong presumption that it may be assigned to so early a period as the first centuries of the second millennium B.c. An unanticipated discovery of a palace extension to the north has led to the uncovering not only of an earlier palace structure of a different orientation, dated tentatively at 1600 B.c., but also of two preceding city walls, and beneath these of the well-preserved remains of an acropolis gateway of the eighteenth, or even the nineteenth, century B.c. According to a description of this work in Sir Leonard's report (The Times, Sept. 3) it is an imposing structure, roughly seventy-five feet square, and consisting of twin towers joined by a bridge roofing the entrance passage. This passage has a system of three doorways. The gateway is built of mud brick reinforced by timbers, with massive limestone-faced piers for door-jambs. It is the prototype of the gates of later Hittite eities, such as Carchemish and Boghaz Keui. Assuming that confirmatory evidence of origin is forthcoming, it is the oldest example of Hittite architecture yet known. The conclusion as to its age and the relation of the succession of remains on the north side are corroborated by evidence from the south side, which includes painted pottery and figurines going back to the first century of the second millennium. Even more interesting, if possible, is the occurrence here of Cypriote pottery, including a sherd dated at three centuries earlier than this type appears in Cyprus itself. This with other evidence, Sir Leonard suggests, appears to demand older mainland archetypes for the wares of Bronze Age Cyprus, and once more illustrates the inter-relations of East and West in the early history of civilization. 